\title{
Biological control of banana black Sigatoka disease with Trichoderma
}

\author{
Controle biológico da Sigatoka-negra da bananeira com Trichoderma
}

\author{
Poholl Adan Sagratzki Cavero ${ }^{\mathrm{I}}$ Rogério Eiji Hanada ${ }^{\mathrm{I}}$ Luadir Gasparotto ${ }^{\mathrm{II}}$ \\ Rosalee Albuquerque Coelho Neto ${ }^{I}$ Jorge Teodoro de Souza ${ }^{\text {III }}$
}

\section{ABSTRACT}

Black Sigatoka disease caused by Mycosphaerella fijiensis is the most severe banana disease worldwide. The pathogen is in an invasive phase in Brazil and is already present in most States of the country. The potential of 29 isolates of Trichoderma spp. was studied for the control of black Sigatoka disease under field conditions. Four isolates were able to significantly reduce disease severity and were further tested in a second field experiment. Isolate 2.047 showed the best results in both field experiments and was selected for fungicide sensitivity tests and mass production. This isolate was identified as Trichoderma atroviride by sequencing fragments of the ITS region of the rDNA and tef-1 $\alpha$ of the RNA polymerase. Trichoderma atroviride was as effective as the fungicide Azoxystrobin, which is recommended for controlling black Sigatoka. This biocontrol agent has potential to control the disease and may be scaled-up for field applications on rice-based solid fermentation.

Key words: antagonists, fungicide sensitivity, mass production, Mycosphaerella fijiensis.

\section{RESUMO}

A Sigatoka-negra causada por Mycosphaerella fijiensis é a doença mais destrutiva da bananeira em termos mundiais. O patógeno está em uma fase invasiva no Brasil e já se encontra distribuido na maior parte dos Estados do país. O potencial de 29 isolados de Trichoderma spp. para o controle da Sigatoka-negra foi estudado sob condições de campo. Quatro isolados foram capazes de reduzir significativamente a severidade da doença e foram selecionados para um segundo experimento de campo. O isolado 2.047 apresentou os melhores resultados e foi utilizado em testes de sensibilidade a fungicidas e produção massal. Esse isolado foi identificado como Trichoderma atroviride por meio do sequenciamento de fragmentos da regiões ITS do
rDNA e tef-1 $\alpha$ da RNA polymerase. Trichoderma atroviride foi tão efetivo no controle da Sigatoka-negra quanto o fungicida Azoxystrobin, que é recomendado para o controle da doença. $O$ agente de controle biológico tem potencial para o controle da Sigatoka-negra e pode ser produzido em massa em arroz autoclavado para aplicações no campo.

Palavras-chave: antagonistas, sensibilidade a fungicidas, produção massal, Mycosphaerella fijiensis.

\section{INTRODUCTION}

Black Sigatoka, caused by Mycosphaerella fijiensis (anamorph Pseudocercospora fijiensis), is considered the most destructive banana disease in Brazil and in several other Latin American countries (SENHOR et al., 2009). The spread of the pathogen to areas where its occurrence was not yet detected is expected to happen in the near future. Black Sigatoka may typically cause losses of around $50 \%$, but it may reach $100 \%$ under certain conditions (PLOETZ, 1991). The pathogen is considerably more difficult to control than yellow Sigatoka, caused by M. musicola and has a wider host range (PLOETZ, 1991).

The disease is occurring in almost all Brazilian States, except for Rio de Janeiro, Espirito Santo, Goiás, Distrito Federal and the Northeastern States (MATOS \& CORDEIRO, 2011). In Amazonas State, many plantations were abandoned due to heavy

IInstituto Nacional de Pesquisas da Amazônia (INPA), Manaus, AM, Brasil.

IIEmbrapa Amazônia Ocidental, Manaus, AM, Brasil.

III Departamento de Fitopatologia, Universidade Federal de Lavras (UFLA), 37200-000, Lavras, MG, Brasil. E-mail: jgeteodoro@gmail.com. Corresponding author. 
losses caused by the pathogen after its arrival at the municipalities of Tabatinga and Benjamim Constant, where susceptible cultivars such as Prata, Maçã, Nanica, Prata graúda and plátano D'Angola were grown (GASPAROTTO et al., 2006).

Fungicide spraying has been the control method most employed for controlling black Sigatoka in banana plantations around the world. In Brazil, owing to the high cost, fungicides are only used in plantations with high levels of technology and yields (GASPAROTTO et al., 2006). In the Amazonian region, fungicide utilization is not feasible because of the high costs and environmental impacts.

The use of resistant cultivars is the ideal strategy, however, factors such as the time frame to develop new cultivars in face of the banana life cycle and its narrow genetic base and the variability of the pathogen that could rapidly adapt to new resistance genes due to its sexual reproduction are complicating factors.

Biological control is an alternative to the use of chemicals (ALABOUVETTE et al., 2006) that may be feasible for some systems. Fungi of the genus Trichoderma are extensively employed as biological control agents of many plant pathogens (RAKHOLIYA, 2010). Among the advantages of using biological agents is the low risk of adverse impacts on the environmental and human health associated with the lower cost of this technology in Brazil. In one of the few studies available on the effect of biological agents against black Sigatoka, Trichoderma isolates were able to inhibit $45 \%$ of M. fijiensis mycelial growth in vitro (ARZATE et al., 2006). However, little is known on the effect of biocontrol agents against this disease under field conditions. In this study, Trichoderma isolates were tested for their effectiveness in field experiments. The most promising isolate was selected for molecular identification, sensitivity to fungicides and mass production.

\section{MATERIALS AND METHODS}

Isolates and inoculum production

All isolates of Trichoderma used in this study were obtained from soil and are preserved in silica-gel (DHINGRA \& SINCLAIR, 1995) and deposited in the microorganism collection of the Institute for Amazonian Research (INPA), in the laboratory for Phytopathology, under accession numbers listed in table 1 . Isolate 2.047 was also deposited under number URM 6702 in the culture collection URM from Pernambuco Federal University
(Recife, PE). To produce spores for field applications, the isolates were grown on Potato Dextrose Agar Medium (PDA) for 5 days under $25^{\circ} \mathrm{C}$. Spore suspensions were adjusted to $10^{7}$ conidia $\mathrm{mL}^{-1}$ and used for field applications.

Screening Trichoderma isolates under field conditions Two-month-old banana plantlets cultivar 'Prata Anã' free of disease symptoms were produced at Embrapa Amazônia Ocidental and used for the field tests. To favor the natural occurrence of disease, plantlets were planted between rows of an old banana plantation heavily infected with $M$. fijiensis established with a spacing of $3 \mathrm{~m}$ between rows and $1.5 \mathrm{~m}$ from each other in the rows. The experiment was installed in a completely randomized design with five replicates of one plant and 30 treatments, composed of 29 isolates of Trichoderma plus one control with distilled water. Leaves $0,1,2$ and 3 were sprayed to run-off with Trichoderma spore suspensions or distilled water. Sprayings were done always after 16:00 $\mathrm{h}$ on both faces of the leaves and were repeated every 10 days for 3 months. Disease severity was evaluated at 60 and 90 days after the first application with the disease index described by GAUHL (1990) that ranges from 0 to 6 , where (0) represents no symptoms; (1) less than $1 \%$ of the leaf tissue lesioned or a maximum of 10 lesions; (2) 1 to $5 \%$ of lesioned leaf tissue; (3) 6 to $15 \%$; (4) 16 to $33 \%$; (5) 34 to $50 \%$ and (6) 51 to $100 \%$ of lesioned leaf tissue.

A second experiment was installed with the four isolates that showed the best results in the first assay. Banana plantlets and spore suspensions were prepared as described for the first assay. However, spraying intervals were reduced to every seven days for a period of 60 days. The experiment was installed in a completely randomized design with ten replicates of one plant and six treatments composed of an untreated control, one fungicide treatment and four isolates of Trichoderma spp. The fungicide Azoxystrobin was applied in the concentration recommended for banana, $250 \mathrm{mg} \mathrm{L}^{-1}$. Severity was evaluated 60 days after the first application according to the disease index described above.

For statistical analyses, severity data of the first experiment, on the $5^{\text {th }}$ leaf at 60 and 90 days after the first spray were transformed with arc sin $\sqrt{X}(100)^{-1}$. Severity in the $6^{\text {th }}$ leaf evaluated in the second experiment, 60 days after the first spray was transformed with arc $\sin \sqrt{\mathrm{X}}+0.5(100)^{-1}$. Comparison of the means was done with Tukey's test at 5\% probability. 
Table 1 - Severity of black Sigatoka in banana trees treated with isolates of Trichoderma spp. under field conditions.

\begin{tabular}{|c|c|c|}
\hline \multirow{2}{*}{ Trichoderma spp. isolates } & \multirow[b]{2}{*}{ **Severity $(\%) 60$ days } & \multirow[b]{2}{*}{90 days } \\
\hline & & \\
\hline 1.416 & $21.6 \mathrm{ab} * * *$ & $28.0 \mathrm{ab}$ \\
\hline 1.340 & $232 \mathrm{ab}$ & $19.9 \mathrm{abc}$ \\
\hline $1.601-\mathrm{B}$ & $28.0 \mathrm{ab}$ & $29.7 \mathrm{ab}$ \\
\hline 2.113 & $29.7 \mathrm{ab}$ & $31.8 \mathrm{ab}$ \\
\hline 2.041 & $22.1 \mathrm{ab}$ & $31.8 \mathrm{ab}$ \\
\hline 1.611 & $21.6 \mathrm{ab}$ & $25.9 \mathrm{abc}$ \\
\hline 2.122 & $18.9 \mathrm{ab}$ & $27.5 \mathrm{ab}$ \\
\hline 2.116 & $23.2 \mathrm{ab}$ & $27.5 \mathrm{ab}$ \\
\hline 1.435 & $24.5 \mathrm{ab}$ & $25.9 \mathrm{abc}$ \\
\hline $1.439-\mathrm{B}$ & $23.2 \mathrm{ab}$ & 14. $6 \mathrm{abc}$ \\
\hline 2.124 & $17.0 \mathrm{ab}$ & $28.0 \mathrm{ab}$ \\
\hline 2.111 & $18.0 \mathrm{ab}$ & $25.9 \mathrm{abc}$ \\
\hline 2.126 & $17.8 \mathrm{ab}$ & $25.9 \mathrm{abc}$ \\
\hline 2.125 & $28.8 \mathrm{ab}$ & $22.1 \mathrm{abc}$ \\
\hline 1.439 & $31.8 \mathrm{ab}$ & $31.8 \mathrm{ab}$ \\
\hline 1.351 & $23.7 \mathrm{ab}$ & $29.7 \mathrm{ab}$ \\
\hline 2.048 & $25.4 \mathrm{ab}$ & $22.1 \mathrm{abc}$ \\
\hline 1.432 & $38.3 \mathrm{a}$ & $34.0 \mathrm{a}$ \\
\hline 2.117 & $29.7 \mathrm{ab}$ & $31.8 \mathrm{ab}$ \\
\hline 2.047 & $12.7 \mathrm{~b}$ & $04.1 \mathrm{c}$ \\
\hline 2.115 & $20.8 \mathrm{ab}$ & $28.0 \mathrm{ab}$ \\
\hline 2.121 & $21.6 \mathrm{ab}$ & $31.8 \mathrm{ab}$ \\
\hline 2.109 & $27.5 \mathrm{ab}$ & $30.2 \mathrm{ab}$ \\
\hline 1.599 & $15.1 \mathrm{~b}$ & $11.1 \mathrm{bc}$ \\
\hline $1.572-3$ & $20.8 \mathrm{ab}$ & $21.1 \mathrm{abc}$ \\
\hline $1.589-\mathrm{B}$ & $22.4 \mathrm{ab}$ & $28.8 \mathrm{ab}$ \\
\hline 2.114 & $23.2 \mathrm{ab}$ & $31.8 \mathrm{ab}$ \\
\hline 2.123 & $25.4 \mathrm{ab}$ & $22.1 \mathrm{abc}$ \\
\hline $1.598-\mathrm{B}$ & $27.5 \mathrm{ab}$ & $31.8 \mathrm{ab}$ \\
\hline Control & $19.4 \mathrm{ab}$ & $30.2 \mathrm{ab}$ \\
\hline
\end{tabular}

*Control plants were treated with distilled water.

**Plants were treated with Trichoderma or distilled water (control) and severity was scored at 60 and 90 days after the inoculation on a 1-to6 scale described by GAUHL (1990). Data were transformed by arc sin vX $(100)^{-1}$.

***Means followed by the same letters are not significantly different by Tukey's test at $5 \%$ probability.

Species identification

Isolate 2.047 was selected for having the highest potential to control black Sigatoka and identified on the basis of morphological characters and by sequencing the ITS region of the ribosomal DNA and a fragment of the translation and elongation factor of the RNA polymerase (tef$1 \alpha)$. DNA extraction, amplifications, sequencing, alignments and dendrogram construction were done as described previously (SAMUELS et al., 2011). Sequences obtained for isolate 2.047 were deposited in EMBL under accession numbers HG325825 (ITS) and HG325833 (tef-1 $\alpha$ ). The following accession numbers of Trichoderma atroviride isolates were used in the comparative analyses performed in this study: GJS95-113 (AF456912; AF456883), DAOM165779 (Z48811; AF456892), GJS98-134 (AF456913; AF456887), CBS119499 (FJ860726; FJ860611), GJS96200 (AJ230666; AF456882), DAOM179514 (EU280125; EU280011), DAOM231423 (EU280111; EU280002).

Sensitivity to fungicides

The fungicides Clorotalonil at $1200 \mathrm{mg}$ $\mathrm{L}^{-1}$, Flutriafol at $75 \mathrm{mg} \mathrm{L}^{-1}$, Copper Oxychloride at $1400 \mathrm{mg} \mathrm{L}^{-1}$ and Azoxystrobin at $250 \mathrm{mg} \mathrm{L}^{-1}$ were tested on conidial germination. These concentrations 
are recommended by their respective manufacturers for controlling fungal diseases. Conidial suspensions of isolate 2.047 containing $10^{7}$ conidia $\mathrm{mL}^{-1}$ were prepared in each fungicide and sterile distilled water was used as control. Samples of $100 \mu \mathrm{L}$ were taken at $0,30,60,90,120$ and $180 \mathrm{~min}$, spread on PDA plates and incubated at $25^{\circ} \mathrm{C}$ in three replicates per incubation time. This experiment was installed in a randomized design, with a $6 \times 6$ factorial scheme, where the first factor represents the 6 incubation periods and the second the fungicides and the control, with three replicates per treatment. Sixteen hours after spreading the suspensions on the plates, conidia germination was determined under the microscope. Conidia germination data was transformed with arc $\sin \sqrt{ } \mathrm{X}+0.5(100)^{-1}$ and the means of the treatments compared with the Tukey test at $5 \%$.

\section{Mass production}

Isolate 2.047 was grown in plastic bags containing $200 \mathrm{~g}$ of autoclaved rice with different humidity. The experiment was installed in a randomized design with a factorial scheme $2 \times 2 \times 3$, where the first factor was polypropylene bags that were either kept closed or open after three days of mycelial growth; the second factor was addition or not of $0.03 \mathrm{~g} \mathrm{~mL}^{-1}$ of $\mathrm{CaCO}_{3}$; and three humidity levels: 30,50 and $70 \%$, with three replicates per treatment. Five 5-mm diameter mycelial discs were added to each bag and every two days the chunks of rice were manually broken to allow better aeration. Conidia were counted with a Neubauer chamber after seven days of incubation at $25^{\circ} \mathrm{C}$ and a photoperiod of $12 \mathrm{~h}$ of light. Comparison of the means was done with Tukey's test at 5\%.

\section{RESULTS AND DISCUSSION}

Among the 29 Trichoderna isolates tested under field conditions to control black Sigatoka, only four were able to reduce disease severity to values lower than $20 \%$ at 90 days after the beginning of the experiment (Table 1). This reduction in severity provided by the antagonistic isolates was equivalent to $34-86 \%$ in relation to the untreated control (Table 1). In a second experiment, these four isolates were tested with a higher frequency of application. In this field experiment, disease severity did not differ significantly between isolate 2.047 and the chemical treatment with fungicide azoxystrobin (Table 2). Severity reductions provided by isolate 2.047 and the fungicide azoxystrobin were 66 and $82 \%$, respectively. The severity reductions obtained by isolate 2.047 were the highest among all Trichoderma isolates in both experiments.

The few studies conducted to evaluate isolates of Trichoderma to control M. fijiensis in banana were done in vitro (ARZATE et al., 2006) or under greenhouse conditions (BIZERRA et al., 2006). The results reported herein are the first to our knowledge obtained in an attempt to control black Sigatoka under field conditions. It is recognized that further studies still need to be carried out to gather more information on the activity of this isolate in other phases of banana development, including fruit set.

Several species of the genus Trichoderma are known to be antagonists of pathogenic fungi, but their antagonistic potential depends on the species and on the isolate. Trichoderma species exert biocontrol activity by mechanisms such as micoparasitism, competition for space and nutrients, and induction of resistance (GUEDEZ et al., 2009). The studies reported herein were focused on the activity of Trichoderma isolates under field conditions without determining the mechanism of action at this moment. Further studies should be directed to reveal the mechanisms by which isolates such as 2.047 utilize to suppress M. fijiensis. Nevertheless, recent studies show that Trichoderma is essentially mycotrophic (ATANASOVA et al., 2013) and thus, mycoparasitism is expected to be involved in the activity of this antagonist against $\boldsymbol{M}$. fijiensis. Coincidentally, among the three species profiled in their mycoparasitic activity, T. atroviride was shown to be the most aggressive (ATANASOVA et al., 2013).

In the field experiments, high concentrations of $\boldsymbol{M}$. fijiensis inoculum were maintained throughout the entire experimental period. Trichoderma was sprayed only on the experimental

Table 2 - Severity of black Sigatoka 60 days after inoculation of banana plants in the field.

\begin{tabular}{ll}
\hline Treatments & Severity $(\%)^{*}$ \\
\hline Control & $79.8 \mathrm{a} * *$ \\
1.340 & $52.2 \mathrm{ab}$ \\
$1.439-\mathrm{B}$ & $73.9 \mathrm{a}$ \\
1.599 & $66.9 \mathrm{a}$ \\
2.047 & $27.1 \mathrm{bc}$ \\
Azoxystrobin & $13.8 \mathrm{c}$ \\
\hline
\end{tabular}

* Treatments were applied at every 7 days and severity was scored on a 1-to-6 scale described by GAUHL (1990). Data were transformed by arc sin $\mathrm{v} X+0.5(100)^{-1}$.

**Means followed by the same letters are not significantly different by Tukey's test at $5 \%$ probability. 
plots but all plants growing around were continuously releasing spores of the pathogen. Although isolate 2.047 was as effective as the chemical fungicide, the high inoculum pressure in the field may have limited its capacity to further reduce disease severity.

Only isolate 2.047 was selected for identification by morphological and molecular methods because of its superior performance as a biocontrol agent. Morphological characteristics were similar to Trichoderma harzianum but sequences of the ITS region of the ribosomal DNA of isolate 2.047 were $100 \%$ identical to other sequences of T. atroviride deposited in public databases (e.g. KC895539; KC506274; JF694930). Sequences of a fragment of the translation and elongation factor 1- $\alpha$ were $99 \%$ identical to other sequences of $\boldsymbol{T}$. atroviride from public databases (e.g. DQ307548; DQ307550; DQ307547). The combined analyses of these two fragments confirm the identity of isolate 2.047 as $\boldsymbol{T}$. atroviride. It is also possible to observe that there is a considerable diversity in populations of $\boldsymbol{T}$. atroviride from different geographic origins (Figure 1).

The highest production of conidia by isolate 2.047 was obtained in autoclaved rice amended with $\mathrm{CaCO}_{3}$ and with $50 \%$ humidity kept in bags that were opened at 3 days after inoculation. Maximum amount of conidia produced was $2.3 \times 10^{9}$ spores $^{-1}$ of rice (Figure 2). This spore concentration is similar to what was obtained by HANADA et al. (2009) with Trichoderma martiale on rice with different amendments.
Solid fermentation on rice as a substrate is commonly employed to produce fungal spores in Brazil due to its effectiveness, ease of finding it in local markets and reduced cost (POMELLA et al., 2007). Addition of calcium increased the sporulation in these studies and was also observed by other authors (WUYEP et al., 2003). This increase is probably due to $\mathrm{pH}$ stabilization and mineral nutrition (KRISHNA, 2005). Although no economical evaluation was done in this study, the production of conidia on rice does not require a significant investment. This process could be scaled-up by using artisanal methods and this characteristic may facilitate the commercialization of the biocontrol agent.

The germination of conidia of isolate 2.047 was not inhibited by the fungicides Chlorotalonil, Flutriafol, Copper Oxychloride, and Azoxystrobin after an exposition of three hours (Data not shown). This exposure time was normally enough to perform the preparation and application of the spores under field conditions. This suggests that combined applications of the biocontrol agent with fungicides may be performed when required from the standpoint of the integrated disease management of the disease.

\section{CONCLUSION}

Trichoderma atroviride 2.047 is the first isolate of this genus to show potential to control banana black Sigatoka under field conditions. This

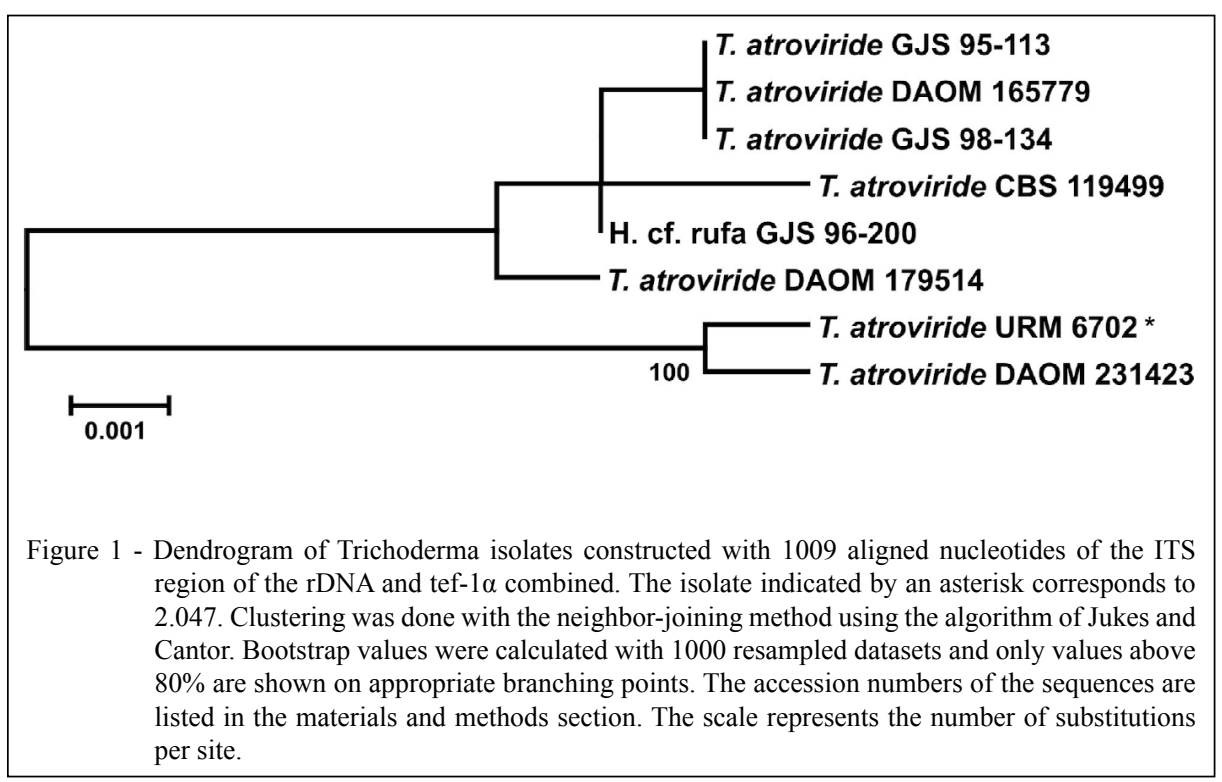

Ciência Rural, v.45, n.6, jun, 2015. 


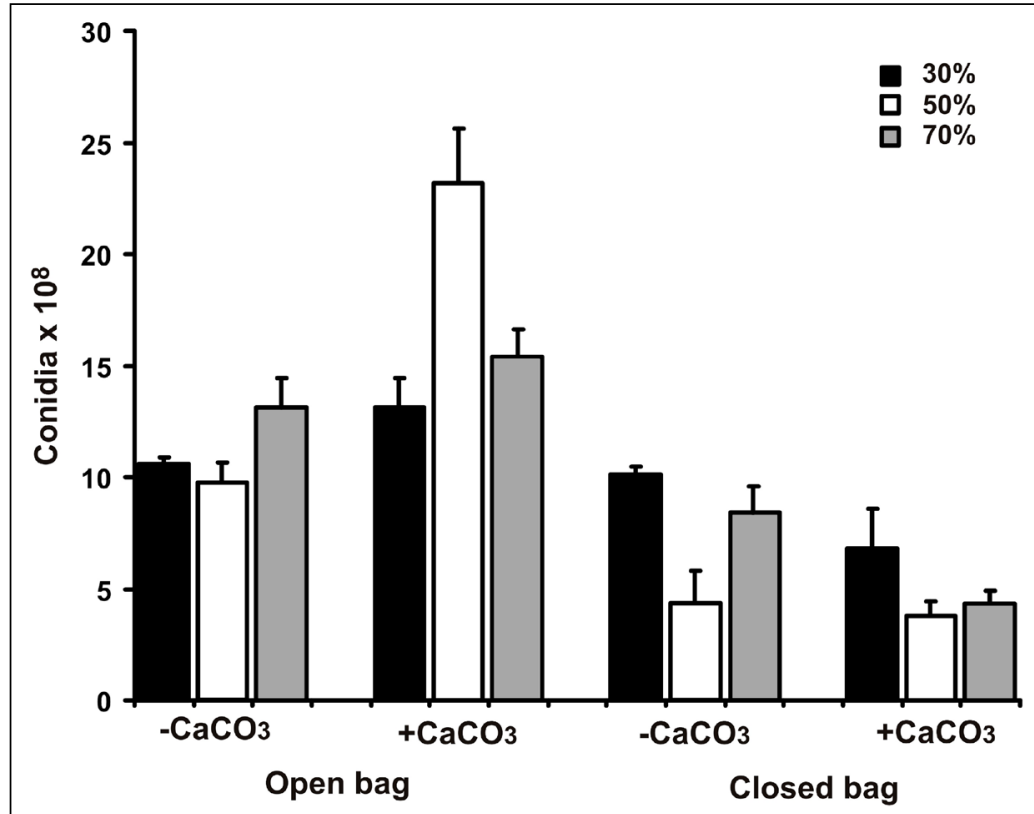

Figure 2 - Production of conidia by isolate 2.047 of Trichoderma atroviride on autoclaved rice. Rice was maintained with three humidity levels (30, 50 and 70\%) and amended or not with $\mathrm{CaCO}_{3}$ and incubated under a 12-h photoperiod for 7 days in polypropylene bags that were or were not open after 3 days after seeding the rice with conidia. Error bars represent the standard error of the means.

isolate was selected among 29 others for being able to reduce the severity of back Sigatoka to levels similar to the ones provided by the fungicide Azoxystrobin. Spores of this isolate may be produced in rice-based solid fermentation for field applications.

\section{ACKNOWLEDGEMENTS}

The first and last authors acknowledge respectively, the receipt of a study scholarship from Fundação de Apoio a Pesquisa do Estado do Amazonas (FAPEAM) and a productivity scholarship from Conselho Nacional de Desenvolvimento Científico e Tecnológico (CNPq).

\section{REFERENCES}

ALABOUVETTE, C. et al. Biological control of plant diseases: the European situation. European Journal of Plant Pathology, v.114, p.329-341, 2006. Available from: $<$ http://link.springer.com/ article/10.1007\%2Fs10658-005-0233-0\#page-1>. Accessed: Nov. 20, 2013. doi:10.1007/s10658-005-0233-0.

ARZATE, J. et al. A ntagonismo de Trichoderma spp. sobre Mycosphaerella fijiensis Morelet, agente causal de la Sigatoka negra del Plátano (Musa sp.) in vitro e invernadero. Revista Mexicana de Fitopatologia, v.24, p.98-104, 2006. Available from: $<$ http://www.redalyc.org/pdf/612/61224203.pdf $>$. Accessed: Nov. $21,2013$.
ATANASOVA, L. et al. Comparative transcriptomics reveals different strategies of Trichoderma mycoparasitism. BMC Genomics, v.14, n.121, p.1-15, 2013. Available from: <http:// www.biomedcentral.com/1471-2164/14/121/>. Accessed: Jan. 05, 2014. doi:10.1186/1471-2164-14-121.

BIZERRA, S.M. et al. Potencialidade de diferentes isolados de Trichoderma spp. no controle de Mycosphaerella fijiensis, agente causal da Sigatoka negra. Biológico, v.68, p.29-86, 2006. Available from: <http://www.biologico.sp.gov.br/docs/bio/v68_1_2 /p71. pdf $>$. Accessed: Nov. 01, 2013.

DHINGRA, O.D.; SINCLAIR, J.B. Basic plant pathology methods. Boca Raton: Lewis Publishers, 1995. 434p.

GASPAROTTO, L. et al. Sigatoka negra da bananeira. Brasília: Embrapa Amazônia Ocidental, 2006. 177p.

GAUHL, F. Epídemiologia y ecologia de la Sigatoka negra (Mycosphaerella fijiensis Morelet) en plátano (Musa sp.) en Costa Rica. Panamá City: UPEB, 1990. 126p.

GUEDEZ, C. et al. Efecto antagonico de Trichoderma harzianum sobre algunos hongos patogenos postcosecha de la fresa (Fragaria spp.). Revista de la Sociedad Venezolana de Microbiologia, v.29, p.34-38, 2009. Available from: <http://www.scielo.org.ve/ scielo.php?pid=S1315-25562009000100007\&script=sci_arttext $>$. Accessed: Nov. 11, 2013.

HANADA, R.E. et al. Biocontrol potential of Trichoderma martiale against black-pod disease (Phytophthora palmivora) of cacao.

Ciência Rural, v.45, n.6, jun, 2015. 
Biological Control, v.50, 143-149, 2009. Available from: <http:// www.sciencedirect.com/science/article/pii/S1049964409001030>. Accessed: Nov. 11, 2013. doi: 10.1016/j.biocontrol.2009.04.005.

KRISHNA, C. Solid-state fermentation systems - an overview. Critical Reviews in Biotechnology, v.25, p.1-30, 2005. Available from: <http://www.ncbi.nlm.nih.gov/pubmed/15999850>. Accessed: Dec. 21, 2013.

MATOS, A.P.; CORDEIRO, Z.J.M. O patógeno e sua distribuição geográfica. In: CORDERO, Z.J.M. Recomendações técnicas sobre a Sigatoka-negra da bananeira. Cruz das Almas: Embrapa Mandioca e Fruticultura, 2011. Chap.2, p.15-25.

PLOETZ, R.C. Black Sigatoka of banana. The Plant Health Instructor, 2001. Available from: <https://www.apsnet.org/ publications/apsnetfeatures/Pages/blacksigatoka.aspx $>$. Accessed: Nov. 20, 2013. doi: 10.1094/PHI-I-2001-0126-02.

POMELLA, A.W.V. et al. The use of Trichoderma stromaticum in the management of witches' broom disease of cacao in Bahia State, Brazil. In: VINCENT, C. Biological control: a global perspective - case studies from around the world. Wallingford: CABI Publishing, 2007. Chap.23, p.210-217.
RAKHOLIYA, K.B. Efficacy of fungicides against Trichoderma harzianum and Sclerotium rolfsii. International Journal of Plant Protection, v.3, p.406-407, 2010. Available from: <http:// www.connectjournals.com/file_html_pdf/837402H_3_406407_A.pdf>. Accessed: Nov. 25, 2013.

SAMUELS, G.J. et al. Trichoderma stromaticum and its overseas relatives. Mycological Progress, v.11, 215-254, 2011. Available from: <http://link.springer.com/article/10.1007\%2Fs11557-011 -0743-4>. Accessed: Nov. 20, 2013. doi:10.1007/s11557-0110743-4.

SENHOR, R.F. et al. Manejo integrado de Sigatoka negra. Revista Verde, v.4, p.7-12, 2009. Available from: <http://www. gvaa.com.br/revista/index.php/RVADS/article/viewFile/185/185>. Accessed: Nov. 13, 2013.

WUYEP, P.A et al. Production and regulation of lignin degrading enzymes from Lentinus squarrosulus (Mont.) Singer and Psathyrella atroumbonata Pegler. African Journal of Biotechnology, v.2, p.444-447, 2003. Available from: $<$ https:// tspace.library.utoronto.ca/handle/1807/1519>. Accessed: Nov. $20,2013$. 